\title{
Use of fuel cell and solar energy to supply the energy required for an educational building in the cold climate of HamedanCase study: Application of polymer electrolyte membrane fuel cell to supply heat and power for Farabi Administrative-Educational Building
}

\author{
Shahab Nooshmand ${ }^{1}$ and Asad Mortezaei ${ }^{2}$ \\ ${ }^{1}$ Islamic Azad University of Hamedan \\ ${ }^{2} \mathrm{Bu}$ Ali Sina University
}

January 23, 2022

\begin{abstract}
Environmental considerations are among the main reasons for selecting fuel cells as a strategic approach. To conduct a feasibility study for the application of a combined system in residential buildings for thermal energy (heat) and electricity (power) production, this paper comprehensively investigated the use of polymer fuel cells and solar energy in Farabi AdministrativeEducational Building in the Islamic Azad University, Hamedan Branch, Iran. This educational building is located in the cold arid climate of Hamadan, which is a high-altitude city, and its working hours coincide with solar radiation hours. The use of electricity produced by photovoltaic (PV) panels for hydrogen generation is a new effort to use solar energy in classrooms. Attempts were made to produce the fuel used in polymer fuel cells, i.e., hydrogen, by a polymer electrolyzer and solar energy with the objective of supplying electricity to Farabi Building with the highest cost-effectiveness. Part of thermal energy is supplied by heat removed from the fuel cell. The process was analyzed with the help of TRNSYS energy processor. According to the results, $4923 \mathrm{~kW}$ electricity is obtained by installing the designed system, reducing carbon dioxide production by 5662200 $\mathrm{g}$ on average.
\end{abstract}

\section{Hosted file}

Manuscript.docx available at https://authorea.com/users/456745/articles/553734-use-of-fuelcell-and-solar-energy-to-supply-the-energy-required-for-an-educational-building-in-thecold-climate-of-hamedancase-study-application-of-polymer-electrolyte-membrane-fuel-cellto-supply-heat-and-power-for-farabi-administrative-educational-building

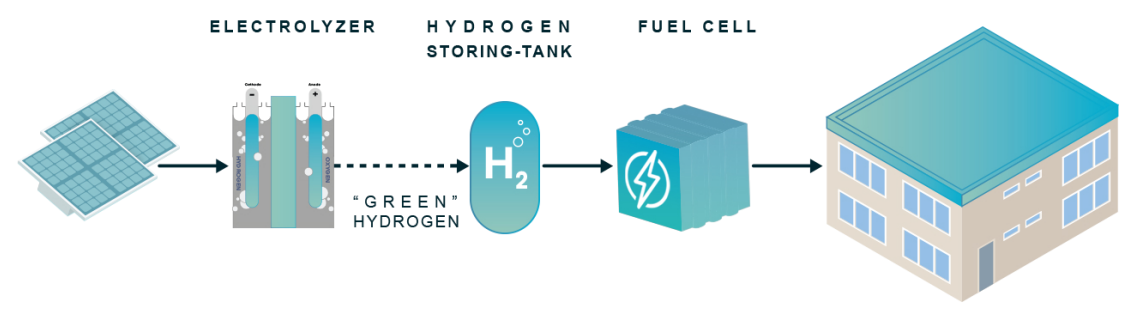

